\title{
微生物が地盤の隆起の原因になっていることを 探る実験的研究
}

\author{
山中健生* ·宮坂秀一* ·庄子和夫* · 陽田秀道**
}

\section{Experimental Verification of Bacterial Cause of Upheaval of the Ground}

\author{
Tateo YAMANAKA*, Hidekazu MIYASAKA*, Kazuo SHOJI* and Hidemichi YouTA**
}

\begin{abstract}
The damage by upheaval of the residential land of houses built on the mudstone of the Miocene has been reported in Iwaki-city area, Fukusima prefecture, Japan. The present studies were performed intending to clarify the reasons why the land was upheaved. When the fresh mudstone was added to the culture medium for Thiobacillus novellus supplemented with sodium sulfide, the $\mathrm{pH}$ of the medium decreased from 8 to 3.2 during 7 day-cultivation at $28^{\circ} \mathrm{C}$. When the mudstone was added to the medium for Thiobacillus ferrooxidans in which ferrous sulfate was replaced by powdered pyrite and $\mathrm{pH}$ was adjusted to 7 , the $\mathrm{pH}$ of the medium decreased from 7 to 2 , and the concentrations of ferrous and ferric ions in the medium greatly increased. When the mudstone sterilized at $121^{\circ} \mathrm{C}$ for $20 \mathrm{~min}$ was used, neither the decrease of the $\mathrm{pH}$ nor the increase in the concentrations of ferrous and ferric ions was observed. Therefore, the microorganisms, sulfur oxidizing and acidophilic iron oxidizing bacteria, in the mudstone seemed to have oxidized pyrite to form sulfuric acid if sulfide was available, even though the initial $\mathrm{pH}$ of the mudstone was $7-8$. Sulfuric acid thus formed will form gypsum which seems to be one of the causes of upheaval of the ground.
\end{abstract}

\section{1. はじめに}

近年，中新世の未風化泥岩地盤に建設した住宅の床下 の地盤や, 工場の床版下の地盤が隆起する盤膨れ現象が 福島県いわき市を中心に起こっており，これによる被害 が社会問題になっている. 切土して露出した未風化泥岩 のpHは 7-9であり, この未風化泥岩を空気に曝してお くと数力月でpHが 4 から 2 付近まで低下する．このよう な泥岩を調べた結果, 硫酸還元菌, 硫黄酸化細菌, 好酸 性鉄酸化細菌が生息することが明らかになった。また， 盤膨れを起こした土壤の表面には石膏が晶出し, 光沢を 示している。このような現象を，陽田1は，次のような 機構に基づき考察している. すなわち, 切土した未風化 の泥岩上に住宅や工場を建築することにより, 床下温度

1996年10月17日受付, 1996年11月28日受理

* 日本大学理工学部

Department of Industrial Chemistry, College of Science and Technology, Nihon University, Kanda-Surugadai, Chiyoda-ku, Tokyo 101, Japan

**(株) ヨウタ

Youta Co., 3 Ojima-machi 12-2, Iwaki-city, Fukusima 973, Japan
が上昇し，それに伴い泥岩の温度も上昇し，未乾燥の嫌 気的条件下で硫酸還元菌が $\mathrm{H}_{2} \mathrm{~S}$ を発生する. $\mathrm{H}_{2} \mathrm{~S}$ が泥岩 の乾燥に伴い空気に触れると, 硫黄酸化細菌の作用によ $り \mathrm{H}_{2} \mathrm{SO}_{4}$ が生じ $\mathrm{pH}$ が 4 付近まで低下する. 次の段階で 好酸性鉄酸化細菌が活動を始め, 土中のパイライト $\left(\mathrm{FeS}_{2}\right)$ を酸化して $\mathrm{H}_{2} \mathrm{SO}_{4}$ を生成する.この $\mathrm{H}_{2} \mathrm{SO}_{4}$ がカルシ

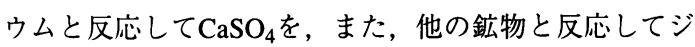
ヤロサイトを生成する．このような二次鉱物の生成を伴 う生化学的風化作用のため, 泥岩の破砕や粉化が起こり 土壤の体積が膨張する。

本研究では，この陽田1の予想が正しいかどうかを明 らかにするため, 盤膨れの起こる地区の泥岩を用いて, その中に生息する微生物によりパイライトが酸化される かどうかを調べた.

\section{2. 実験方法}

まず，硫黄酸化細菌用の培地 $(\mathrm{pH} 7-8)$ に泥岩を入れ振 とう培養すると $\mathrm{pH}$ が低下すること(つまり泥岩中に硫黄 酸化細菌がいること)および, 好酸性鉄酸化細菌用の培 地 $(\mathrm{pH} 2$ )に泥岩を入れて振とう培養すると Fe(II)が $\mathrm{Fe}(\mathrm{III})$ に酸化されること(つまり泥岩中に好酸性鉄酸化細菌が 
いること)を確かめた。次に, 硫黄酸化細菌用の培地 $(\mathrm{pH}$ 7-8)へパイライトを加えたものに泥岩を入れて振とう培 養すると, $\mathrm{pH}$ 低下するとともにパイライトが分解され ることを $\mathrm{Fe}(\mathrm{II})+\mathrm{Fe}(\mathrm{III})$ の増加の測定により明らかにした。 土壤サンプルとしては，いわき市内の造成地の盤膨れ現 象の見られる地区の泥岩を用いた。 以下のいずれの実験 に打いても, 泥岩は宅盤下, 20-70 cmの深さのものを細 粉化して用い, $121^{\circ} \mathrm{C}, 20$ 分間加熱した泥岩を対照とし て用いた。

\section{1 硫黄酸化細菌}

Santerら2)のThiobacillus novellus 用の無機培地に0.2\% $\mathrm{Na}_{2} \mathrm{~S}$ を加え $\mathrm{pH} 7-8$ に調整した溶液 $200 \mathrm{ml} 500 \mathrm{ml}$ 坂 ロフラスコに入れ滅菌した後, 細粉化した泥岩 $10 \mathrm{~g}$ 加 えて $28^{\circ} \mathrm{C} て ゙$ 振とう培養し, $\mathrm{pH}$ の変化を測定した.

\section{2 好酸性鉄酸化細菌}

Silverman とLundgrenの $9 \mathrm{~K}$ 培地 3$)\left(\mathrm{pH} 2,13.3 \mathrm{~g} \mathrm{FeSO}_{4}\right.$. $7 \mathrm{H}_{2} \mathrm{O}$ を含む) $200 \mathrm{ml}$ に細粉化した泥岩 $10 \mathrm{~g}$ 加え $500 \mathrm{ml}$ 坂ロフラスコにいれ $28^{\circ} \mathrm{C}$ で振とう培養し, $\mathrm{Fe}(\mathrm{III})$ の生成 量をロダン塩法4)で測定した。

\section{2. $3 \mathrm{pH} 2$ におけるパイライトの酸化}

Silverman とLundgrenの $9 \mathrm{~K}$ 培地3) $200 \mathrm{ml} \mathrm{FeSO}_{4}$ の代り に細粉化したパイライト $5 \mathrm{~g}$ を加え， $\mathrm{pH} 2$ に調整した のち細粉化した泥岩 $10 \mathrm{~g}$ 加えて $28^{\circ} \mathrm{C} て ゙$ 振とう培養して, $\mathrm{Fe}(\mathrm{II})+\mathrm{Fe}(\mathrm{III})$ の生成量を 0 -フェナントロリン法5)で測定し た。好酸性鉄酸化細菌が存在すると, 式(1)のように, パイライトの硫黄は酸化されて硫酸になるが $\mathrm{Fe}$ なって溶解する． $\mathrm{Fe}^{2+}$ は一部が酸化されるので，培養液 中には $\mathrm{Fe}(\mathrm{II})+\mathrm{Fe}(\mathrm{III})$ が増加する6).

$\mathrm{FeS}_{2}+7 / 2 \mathrm{O}_{2}+\mathrm{H}_{2} \mathrm{O} \longrightarrow \mathrm{Fe}^{2+}+2 \mathrm{SO}_{4}{ }^{2-}+2 \mathrm{H}^{+}$

\section{4 泥岩中の細菌によるパイライトの酸化}

T. novellus 用の培地 $\left(\mathrm{pH} 7\right.$ - 8)に $0.5 \% \mathrm{Na}_{2} \mathrm{~S}$ を加えたも の $200 \mathrm{ml}$ に細粉化したパイライトを加え, さらに, 細粉 化した泥岩 $10 \mathrm{~g}$ を加えて $500 \mathrm{ml}$ 坂ロフラスコに入れ $28^{\circ} \mathrm{C}$ で振とう培養し, $\mathrm{Fe}(\mathrm{II})+\mathrm{Fe}$ (III)の生成量をo-フェナントロ リン法5)で測定した。

\section{3. 実験結果と考察}

T. novellus 用培地に $\mathrm{Na}_{2} \mathrm{~S}$ を追加して泥岩を加えた場 合は次第にpHが低下し，用いた土の中に硫黄酸化細菌が 生息することを示した(Fig. 1A). しかし，T. novellus 用 培地に $\mathrm{Na}_{2} \mathrm{~S}$ 添加しない培地では $\mathrm{Na}_{2} \mathrm{~S}_{2} \mathrm{O}_{3}$ が存在するに も係わらずpHの低下が見られなかった(Fig. 2A).この結 果は, この泥岩の中の硫黄酸化細菌が $\mathrm{Na}_{2} \mathrm{~S}_{2} \mathrm{O}_{3}$ を酸化で きないことを示した. また，Fig. 3Aに示すように，泥岩 はpH 2 において $\mathrm{Fe}(\mathrm{III})$ Fe(III)に酸化したので，この土の

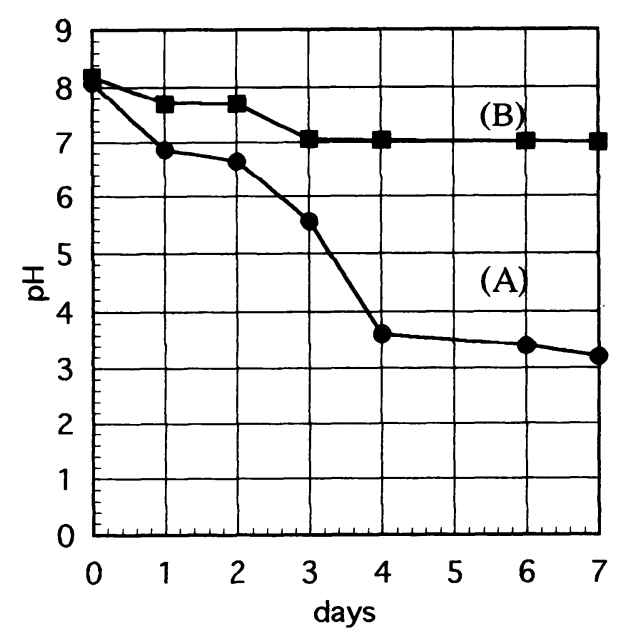

Fig. 1 The pH change observed when the culture medium for Thiobacillus novellus supplemented with sodium sulfide ( $\mathrm{pH} 7-8$ ) was shaken at $28^{\circ} \mathrm{C}$ in the presence of mudstone. The medium contained sodium sulfide and sodium thiosulfate as the sulfur compounds. (A) mudstone without heat-treatment was added, (B) mudstone heated at $121^{\circ} \mathrm{C}$ for $20 \mathrm{~min}$ was added.

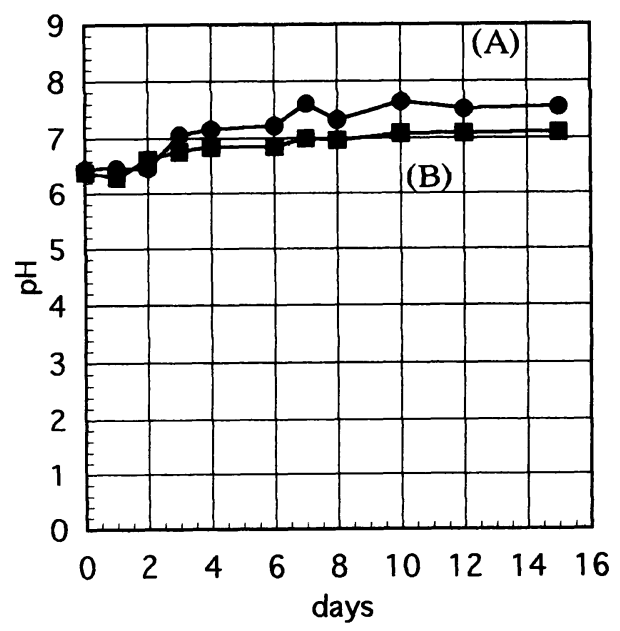

Fig. 2 The $\mathrm{pH}$ change observed when the culture medium for Thiobacillus novellus $(\mathrm{pH} 7)$ was shaken at $28^{\circ} \mathrm{C}$ in the presence of mudstone. The medium contained only sodium thiosulfate as the sulfur compound. (A) mudstone without heat-treatment was added, (B) mudstone heated at $121^{\circ} \mathrm{C}$ for $20 \mathrm{~min}$ was added.

中に好酸性鉄酸化細菌が生息することが示された．Fig. 4Aは，pH 2 において泥岩によりパイライトが酸化され， $\mathrm{Fe}(\mathrm{II})+\mathrm{Fe}(\mathrm{III})$ が生成することを示している．また，Fig. 5A， $\mathrm{C}$ は, $\mathrm{Na}_{2} \mathrm{~S}$ が存在すれば $\mathrm{pH} 7$ から出発しても泥岩によ ク $\mathrm{pH}$ 次第に低下し，それに伴ってパイライトが酸化さ 


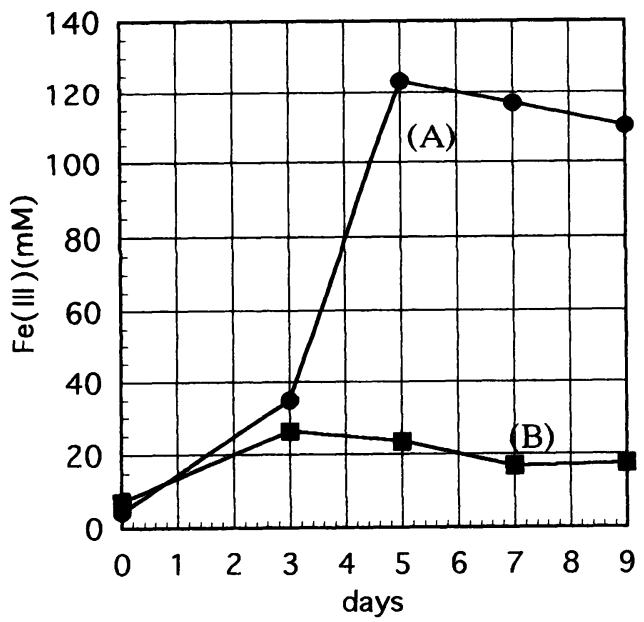

Fig. 3 The increase in the concentration of Fe(III) observed when the culture medium for Thiobacillus ferrooxidans ( $\mathrm{pH}$ 2) was shaken at $28^{\circ} \mathrm{C}$ in the presence of mudstone. (A) mudstone without heat-treatment was added, (B) mudstone heated at $121^{\circ} \mathrm{C}$ for $20 \mathrm{~min}$ was added.

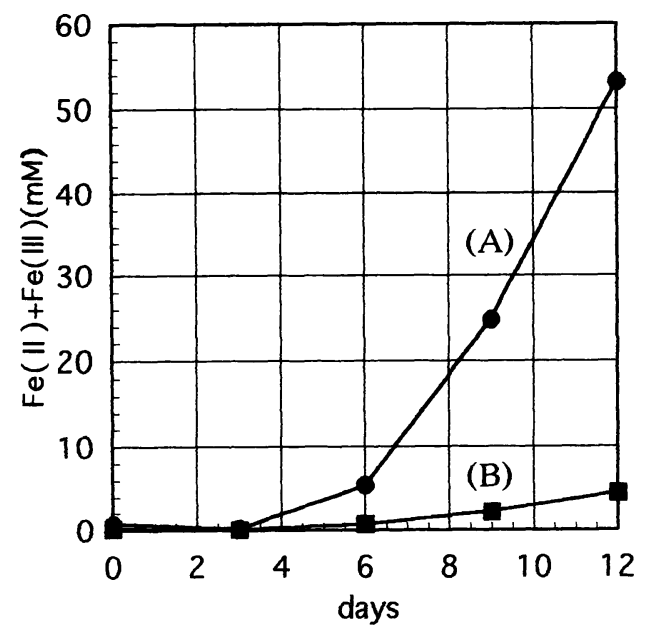

Fig. 4 The increase in the concentration of $\mathrm{Fe}$ (II) $+\mathrm{Fe}$ (III) observed when the culture medium for Thiobacillus ferrooxidans containing pyrite in place of ferrous ion $(\mathrm{pH}$ 2) was shaken at $28^{\circ} \mathrm{C}$ in the presence of mudstone. (A) mudstone without heat-treatment was added, (B) mudstone heated at $121^{\circ} \mathrm{C}$ for $20 \mathrm{~min}$ was added.

れ, $\mathrm{Fe}(\mathrm{II})+\mathrm{Fe}(\mathrm{III})$ が生成することを示している，なお，別 に硫黄酸化細菌としてThiobacillus neapolitanus を用いた 実験で, $\mathrm{pH} 3$ 付近においてもこの細菌のみではパイラ イトを酸化することはできないことを確認した．Fig. 5A, Cに示した実験においては， $\mathrm{H}_{2} \mathrm{~S}$ の代りに $\mathrm{Na}_{2} \mathrm{~S}$ を用いた が, 硫化物があれば泥岩中の細菌により酸化されて $\mathrm{pH}$

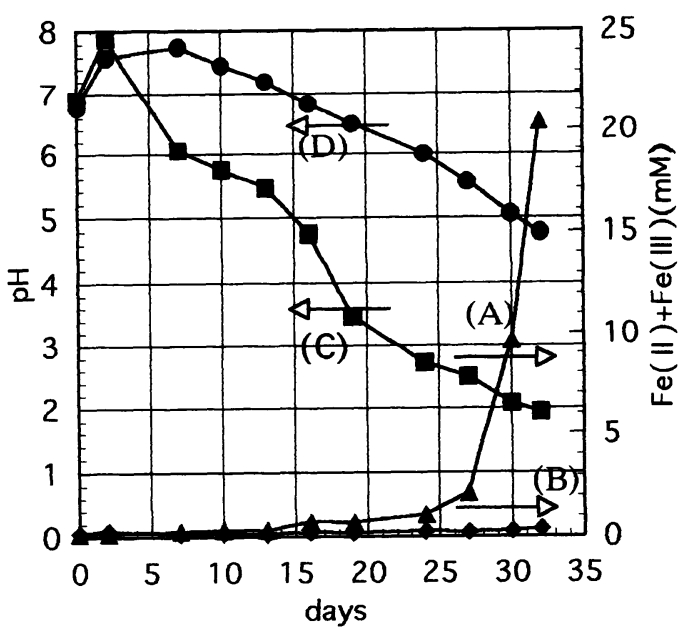

Fig. 5 The increase in the concentration of $\mathrm{Fe}(\mathrm{II})+\mathrm{Fe}(\mathrm{III})$ (A), (B) and the change of $\mathrm{pH}$ (C), (D) observed when the culture medium for Thiobacillus novellus supplemented with $0.5 \% \mathrm{Na}_{2} \mathrm{~S}(\mathrm{pH} 7)$ containing powdered pyrite was shaken at $28^{\circ} \mathrm{C}$ in the presence of mudstone. (A), (C): mudstone without heat-treatment was added; (B), (D): mudstone heated at $121^{\circ} \mathrm{C}$ for 20 min was added.

が低下するとともに，パイライトが酸化されて Fe(II)+ $\mathrm{Fe}(\mathrm{III})$ が生成するので, $\mathrm{SO}_{4} 2$-も式(1)に従って生成する. 従って，陽田川が予想したように，泥岩中の $\mathrm{H}_{2} \mathrm{~S} か ゙$ 硫黄 酸化細菌により酸化されて $\mathrm{pH}$ が低下して，好酸性鉄酸 化細菌が活動し多量の $\mathrm{SO}_{4}{ }^{2-か ゙}$ 生じるということが本実 験により証明された。 今回の研究では, 硫酸還元菌の作 用を証明できなかったが，用いた泥岩中にこの細菌が生 息することはすでに報告してある1)。大規模な造成にお ける切土の際は，何の臭気も感じられないが，スパン50 $\mathrm{m}$ の大きな工場内の被害面積 $1,200 \mathrm{~m} 2$ 程度を掘削した際 には強い $\mathrm{H}_{2} \mathrm{~S}$ の臭気を感じた。この $\mathrm{H}_{2} \mathrm{~S}$ は硫酸還元菌の 活動によるものと考えられるが，これらがかりに硫酸還 元菌の活動によらないとしても，盤膨れが起こった場所 の土中には $\mathrm{H}_{2} \mathrm{~S} か ゙$ 生じていることを示している.このよう にして生じた $\mathrm{SO}_{4}^{2-か ゙} \mathrm{Ca}^{2+}$ 反応して $\mathrm{CaSO}_{4}$ を生じたり， $\mathrm{Ca}^{2}+$ 以外の鉱物と反応してジャロサイトを生成し，泥岩 の破砕が土壤の体積を膨張させ, 盤膨れの原因になって いると考えられる．実際，比較的乾燥している土中では $\mathrm{CaSO}_{4}$ が晶出している。また, $\mathrm{CaSO}_{4}$ の少ない盤膨れ箇 所ではジャイロサイトの生成が目視できる1)。しかし， 好酸性鉄酸化細菌の作用でパイライトから $\mathrm{SO}_{4}{ }^{2-}$ が多量

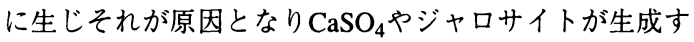
ることは，今後，実験的に証明する必要がある。

謝辞：本研究の一部は, 文部省科学研究費補助金重点領 
域研究「全地球史解読」(領域番号259)の援助を受けまし た.

$$
\text { 文献 }
$$

1) 陽田秀道(1995): 泥岩の微生物及び化学的風化における地 盤の隆起とその被害について. 第40回地盤工学シンポジ ウム, p. 99.

2) Santer, M., Boyer, J. and Santer, U. (1959): Thiobacillus novellus. 1. Growth on organic and inorganic media. J. Bacteriol., 78, 197-202.

3) Silverman, M. P. and Lundgren, D. G. (1959): Studies on the chemoautotrophic iron bacterium Ferrobacillus ferrooxidans. 1. An improved medium and a harvesting procedure for securing high cell yields.J. Bacteriol., 77, 642647.

4) Lazaroff, N. (1963): Sulfate requirement for iron oxidation by Thiobacillus ferrooxidans. J. Bacteriol., 85 , 78-83.

5) Ballentine, R. and Dorothy, D. D. (1957): Determination of metals. Methods Enzymol., 3 1002-1035.

6) DiSpirito, A. A. and Tuovinen, O.H. (1984): Oxidations of nonferrous metals by thiobacilli. In: Strohl, W. R. and Tuovinen, O. H. (eds.) Microbial Chemoautotrophy, Ohio State University Press, Colombus, 3-29 pp. 